\title{
演題番号15
}

\section{Cardioplegia による心筋保護}

\begin{tabular}{llll}
\multicolumn{8}{c}{ 秋田大学医学部附属病院 } \\
斉 藤 & 智 佐 藤 繁 喜 䞇 田 茂 雄 \\
阿
\end{tabular}

\section{緒 言}

開心術に打ける心筋保護は多種多様の方法が行 なわれている，従来の心筋保護法として大動脈切 開を必要とする症例には, 選択的冠灌流法が最も 理想的な心筋保護法と考兄られる。しかし，手技 の繁雑さ，灌流圧，灌流量などの問題点が示唆さ れる。われわれは，先に発表したように大動脈切 開を必要とする症例には逆行性冠灌流による心筋 保護を行ない良好な結果を得ている。一方大動脈 切開を必要としない他の疾患には間歇的大動脈遮 遮断法が最も多く使われて来た。しかし，この方 法は一回の遮断時間，つまり時間的制約がきびし く, また短時間での心拍動停止, 無血視野, 心筋 の十分な弛緩が得られないため，これに変って Cardioplegic Solutionを用いる Cardioplegia 法 が臨床応用されるようになった。

われわれも53年 6 月から crdioplegia 飞 topical cooling を併用した心筇保護法を用いている.これ までに臨床例34例に Cardioplegiaを用いたのでそ の使用方法などについて報告する。

\section{1）方 法}

完全体外循環下に大動脈を遮断し，Ice-tip を 心臓全体にかけ，同時に大動脈基部から大動脈穿 刺針を大動脈壁に 固定し，灌流液 の高さを 80 $100 \mathrm{~cm}$ 水柱からの落差灌流とし, 時にライン途中 の三方活栓より用手パンピングを併用した．大動 脈穿刺針は手術操作終了時の大動脈内空気除去針 としても使用する。

体外循環操作では, 間歇的大動脈遮断法に比較 して, Cardioplegia 法が部分体外循環時間が長く
なっている.これは Caxdioplegic Solutionを使う ことにより心筋の十分な弛緩があるため，心筋の 過伸展にならないように，特に左心ベントを効か せて，左室の容量負荷調節に時間をかけているた めと思われる。また，大動脈遮断解除後の冠状静 脈洞からの冠血流量増大を予測し，より安全性を 考光大動脈遮断解除直前に上下大静脈のテープを 解除することが重要である.

灌流液の組成は（表 1)，Lactated Ringer Solution $500 \mathrm{ml}$ 中に $50 \%$ グルュース $25 \mathrm{ml}, 7 \%$ 重炭 酸ソーダ $15 \mathrm{ml}, \mathrm{Kcl} 10 \mathrm{mEq}$ ，ステロイド $10 \mathrm{mg} / \mathrm{kg}$ である.この灌流液は浸透圧 $340 \mathrm{mOsm}, \mathrm{pH} 7.8$ と なっている。灌流液の温度は $0 \sim 4^{\circ} \mathrm{C}$ ，灌流液注 入開始後 30 秒くらいで完全な心停止が認められ る. 灌流終了時には心筫温は $15^{\circ} \mathrm{C}$ 以下に達し, 弛緩した心臟が得られる。 topical Cooling に用 いる Ice tip は生理食塩水を冷凍庫で水らせ, 電 動式水かき器で細かくすり落したものを使用す る.

表 1

\section{Cardioplegic Solution}

Lactated Ringer $(500 \mathrm{ml})$

$50 \%$ glucose $25 \mathrm{ml}$

$7 \% \quad \mathrm{NaHCO}_{3} \quad 15 \mathrm{ml}$

$\mathrm{KCL} \quad 10 \mathrm{mEq}$

Steroid

$10 \mathrm{mg} / \mathrm{kg}$

Osmotic Pres. $\quad 340 \mathrm{mOsm}$

$\mathrm{pH}$

7.8 
表 2

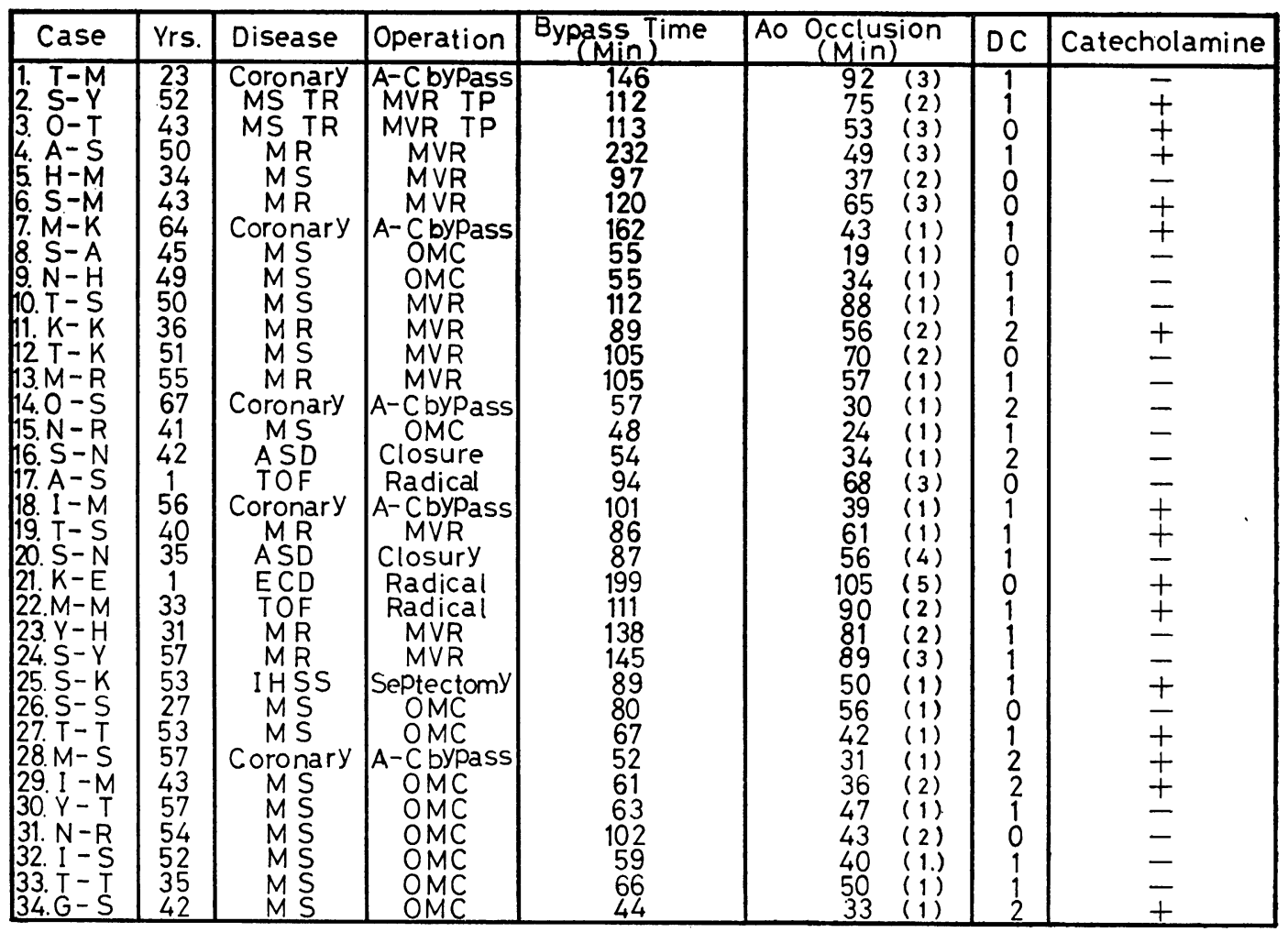

\section{2 ）臨床症例}

臨床例 34 例飞 topical Cooling 併用による Cardioplegia を用いた。 その内訳は表 2 亿示すよ らに, 年齡 $1 \sim 67$ 歳 (平均年齢 46 歳), バイパス時 間44〜232分 (平均バイパス時間97分), 大動脈遮 断時間19１05分（平均大動脈遮断時間54分），か っこ内は大動脈遮断回数で $1 \sim 5$ 回（平均遮断回 数 17 回), 遮断回数 1 回の症例での 大動脈遮断時 間は最低19分から最長88分である.心蘇生時の除 細動回数では34例中 9 例が自然洞調律に復し, 除 細動平均回数0.9回, カテコラミンの使用では, 体 外循環離脱時, あるいは術後カテュラミンを使用 しなかった症例が34例中15例に見られる(表 2). 灌流液の使用量は $50 \sim 1,000 \mathrm{~m} l$ (平均 $365 \mathrm{~m} l$ ) であ った。

\section{3 ）考案・まとめ}

開心術における心筋保護は，手術成績に直接影
響する重要な課題の一つである。近年, Cardioplegia 法の発展は，とくに重症心疾患に対する手 術適応が拡大され，心筋肥大例や心筋障害例に長 時間の大動脈遮断が行なえるようになってきた。 Cardioplegia 法の要素は, 急速な心停止が得ら れ，十分な心筋の弛緩，心筋温を低く維持するこ とである。この中で心筋温を低く保つこと，つま り心筋内外膜層の温度較差をなくすためにも topical Cooling を併用することが重要と思われ る.

われわれは, Cardioplegia に topical Cooling を 併用した心筋保護法を臨床例34例に用いた。しか し，これといった術中の心筋保護効果の判定法が 確立されておらず, これらの研究が課題とされ る. 